\title{
ESTÉTICAS DAS RESISTÊNCIAS E O DOCUMENTÁRIO (DOCUMENTO 02): $A$ DANÇA DA AMIZADE - HISTÓRIAS DE URUCUNGOS, PUÍTAS E QUIJENGUES
}

Gilberto Alexandre Sobrinho Universidade Estadual de Campinas gilsobrinho@iar.unicamp.br

\section{RESUMO}

$\mathrm{Na}$ "Trilogia Afro-Campineira" constam três realizações em documentário, em que dirigi e participei de diferentes estágios da produção. São três curtas-metragens focados em protagonistas de processos culturais, religiosos e artísticos, todos defensores de manifestações de matrizes africanas e seus potentes hibridismos, alocados na região metropolitana de Campinas-SP. Os filmes são Diário de Exus (2015), A Dança da Amizade, Histórias de Urucungos, Puítas e Quijengues (2016) e A Mulher da Casa do Arco-Íris (2017/2018). Desenvolvem-se, nos filmes, o que nomeio como as "estéticas das resistências", priorizando narrativas afro-diaspóricas, num processo de criação em que confluem estética e política. Esteticamente, o documentário faz convergir os processos de observação, participação (entrevista), performance e poesia, num conjunto de imagens e sons centrados em pessoas e espaços que se organizam comunitariamente em torno de códigos afrocentrados. Politicamente, realçam-se o papel da cultura e da religião na afirmação e construção identitária do povo negro, no Brasil, o que adensa a compreensão do papel da cultura na resistência de um povo. Esse texto documenta o processo de realização do segundo curtametragem da trilogia, trata-se de A Dança da Amizade - Histórias de Urucungos, Puítas e Quijengues.

Palavras-chave: Documentário. A Dança da Amizade. Trilogia Afro-campineira.

IMAGEM 01: Still de A Dança da Amizade - Sede do Grupo Urucungos, na Vila Teixeira, em Campinas. (Imagem de Felipe Bomfim)

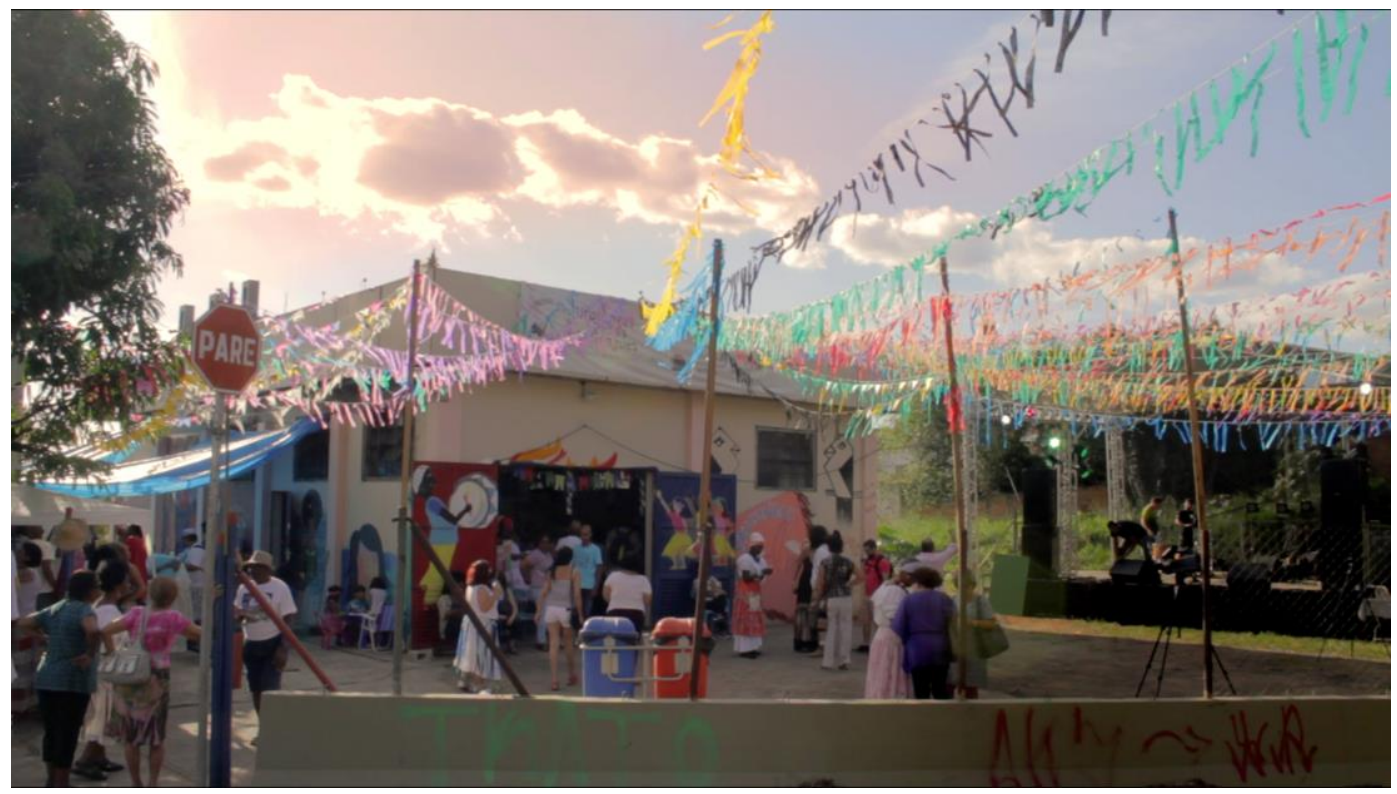


1. O processo de criação, produção e difusão de $A$ Dança da Amizade - Histórias de Urucungos, Puítas e Quijengues (2013-2015)

O ponto de partida foi a realização de um documentário sobre o grupo de arte popular Urucungos, Puítas e Quijengues, de Campinas-SP. À princípio, o objetivo do documentário consistia em capturar imagens das apresentações das danças populares, ou seja, as marcas ritualísticas do passado (transmitidas oralmente e corporalmente) e, posteriormente, a narrativa documentária deslocar-se-ia para o processo de manutenção do legado dos afrodescendentes em diálogo com a africanidade e a negritude presentes na própria cidade de Campinas. Assim, potencialmente, o referido grupo de danças populares se constituiria em terreno fértil para perceber tanto as transformações das tradições rurais do passado em atividades de danças populares e artísticas na atualidade, quanto o movimento de permanente diálogo entre os afrodescendentes entre si e com a cidade, fazendo com que seus repertórios musicais e coreográficos sigam como importante atualização do legado africano e como memória viva. Isso tudo se concretizou e o processo expandiu nossos horizontes de compreensão do próprio grupo, o que ocasionou em mudanças significativas. Aqui estão registrados o projeto, elementos do processo e da exibição, justamente para partilhar o conjunto do desenvolvimento da criação e disseminação do filme.

Cabe esclarecer que junto ao repertório do samba paulista (mais especificamente do Vale do Paraíba, Minas Gerais e Rio de Janeiro e das cidades interioranas do Estado de São Paulo), o grupo "Urucungos" também conjuga danças do Recife e de parte do interior de Pernambuco e Alagoas, onde executam os chamados "Sambas Nordestinos" (Samba de Umbigada, Maracatu, Bumba-meu-boi, Guerreiros). 
IMAGEM 02 - Still de A Dança da Amizade (Imagem de Felipe Bomfim)

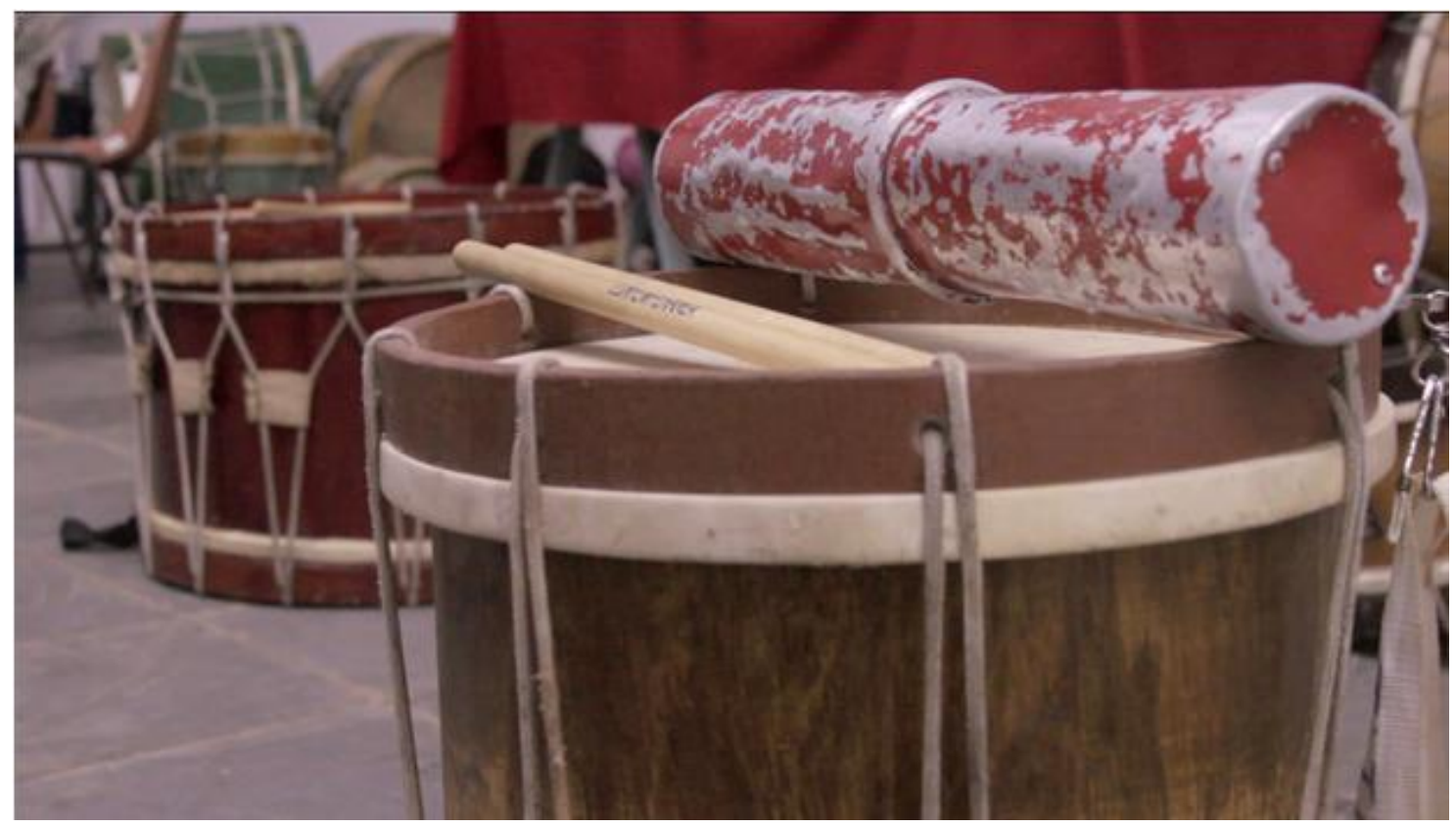

Portanto, diante desses elementos, o desafio e a originalidade deste documentário consistiam em tomar o grupo Urucungos, Puítas e Quijengues, primeiramente para contar sua história e, seguidamente, tê-lo como referência para explorar a produção simbólica de matriz africana e dos seus descendentes em Campinas e no Brasil. É importante observar que a riqueza das imagens entrecruzadas que permeiam o universo do grupo "Urucungos" e sua relação com outros grupos de Campinas não corresponde somente ao resultado da luta por pertencimento dos afro-brasileiros. Como explica Muniz Sodré (2005), no livro "A verdade Seduzida", o mosaico constituído em tempos e espaços distintos também é parte da própria estrutura ontológica africana. Essa estrutura rizomática, movediça também se constitui como parte do legado africano para os nossos tempos. Assim, o documentário pretendeu operar com esses elementos, esclarecendo que o mosaico que constitui as relações entre os diferentes movimentos culturais e religiosos dos negros de Campinas não revela um déficit, mas sim uma outra forma de ver, sentir e agir no mundo. 
IMAGEM 03 - Cartaz oficial de A Dança da Amizade (arte de Claudia Kfouri)

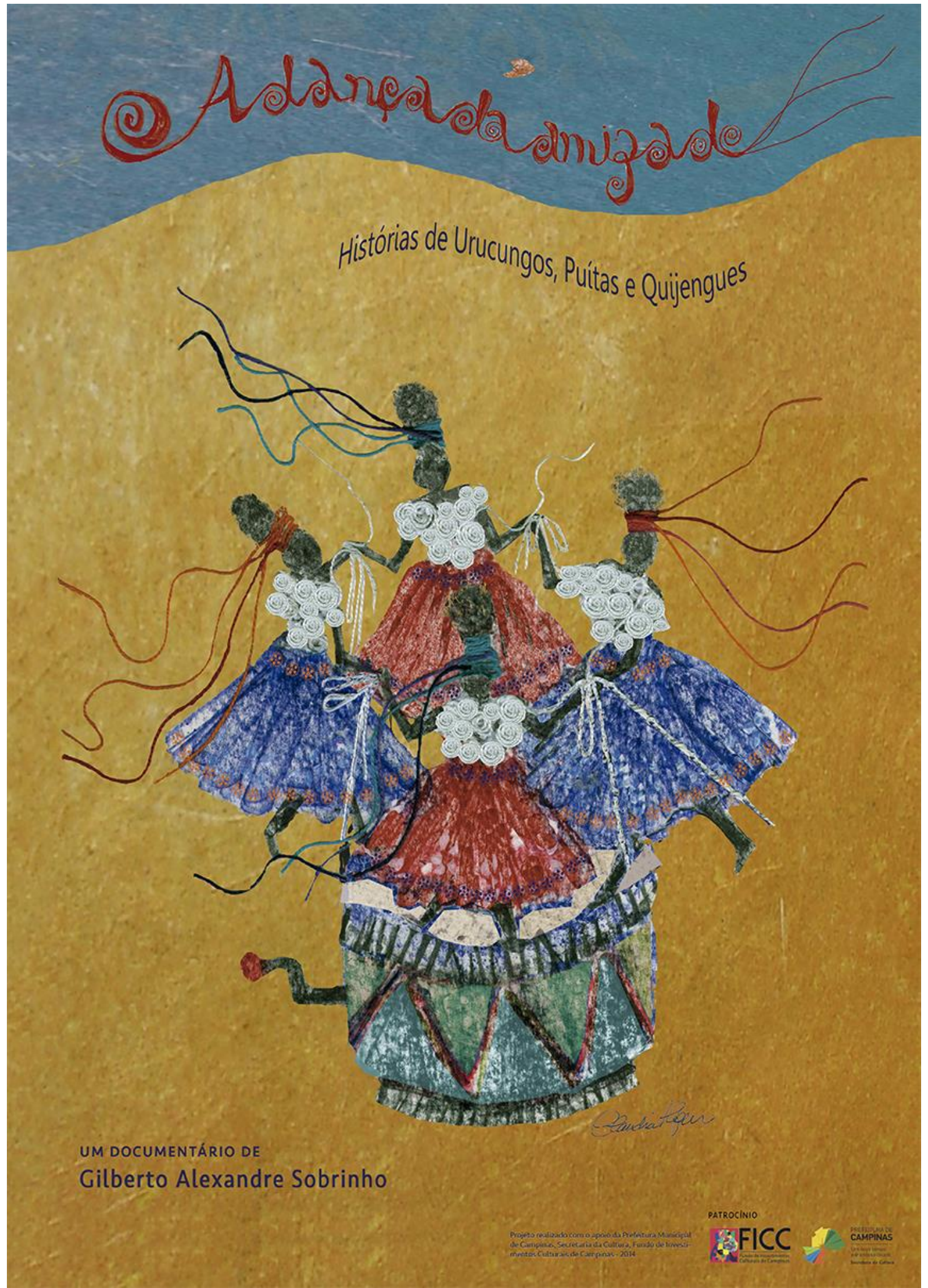

O grupo Urucungos se constitui a partir da entrada da recifense Raquel Trindade (1936-1918), filha do poeta Solano Trindade, primeiramente no curso de dança e, depois, nas artes cênicas, 
da Unicamp. Enquanto artista, pensador e ativista das questões da negritude, Solano Trindade considerava as expressões estéticas da comunidade negra um mecanismo de militância contra a discriminação racial. Ao dar continuidade ao trabalho de seu pai, Raquel Trindade também se esforça para dar visibilidade às expressões artísticas provenientes do legado africano. Ao ministrar a disciplina de Folclore, ela traz para dentro da comunidade acadêmica as expressões populares realizadas pelos afrodescendentes. Sua inserção na universidade corresponde à própria reestruturação do movimento negro na década de 1980, período de redemocratização do país, formação e estabelecimento do MNU - Movimento Negro Unificado, do qual ela era uma das expoentes. Cabe lembrar que diferente de seu pai, Raquel Trindade encontra na religiosidade afro-brasileira um elemento a mais para pôr em visibilidade as expressões estéticas dos afrodescendentes. Durante sua permanência no Instituto de Artes, seu trabalho ganha força e extrapola os espaços da universidade, ecoando na própria comunidade afrodescendente de Campinas. Assim, para além das atividades nos cursos de artes cênicas e dança, ela oferece um curso de extensão universitária de grande impacto. A partir dessa iniciativa surgiu o grupo de danças populares Urucungos... que reverbera os anseios dos seus participantes, e também ecoa as tensões e dificuldades do universo acadêmico em lidar com o legado africano.

IMAGEM 04 - Sinhá Rosália (à esquerda) e Raquel Trindade (à direita), still de A Dança da Amizade (Imagem de Felipe Bomfim)

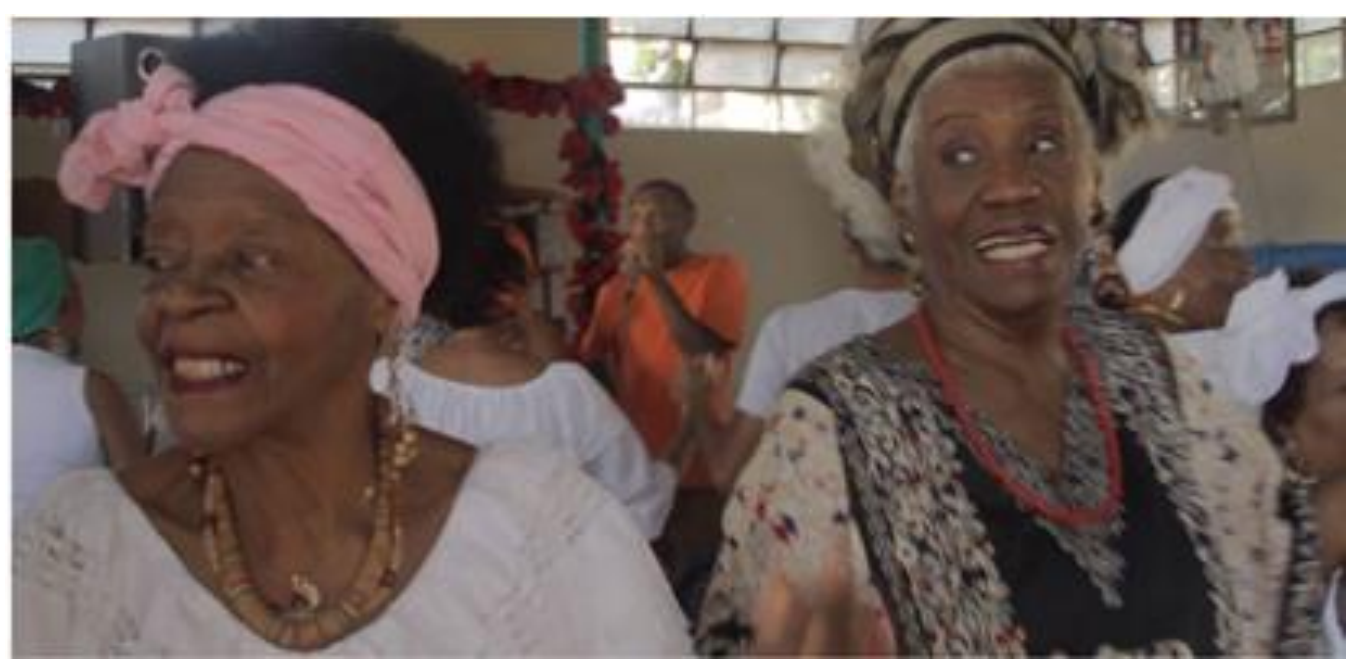

O encontro de Raquel Trindade com a comunidade negra de Campinas faz aflorar peculiaridades do legado africano no interior paulista. Merece destacarmos aqui a presença de Alceu Estevam, que trouxe para o grupo o Samba de Bumbo Campineiro, repertório 
constituído no seio de sua própria família. Neste sentido, a singularidade do Urucungos se ancora na confluência dos saberes nordestinos (via Raquel Trindade) com os saberes do sudeste (via Alceu Estevan). Deste ecletismo surge um vasto repertório do Urucungos. Nele, dança-se o Maracatu, o Bumba-meu-boi, o samba de umbigada, o coco... (expressões nordestinas), mas dança-se também o samba de bumbo campineiro, o samba lenço rural paulista, o jongo (expressões do sudeste).

Portanto, este documentário se justifica pela possibilidade de registrar e conservar todos estes encontros e tensões na forma de documento audiovisual. Nossa perspectiva é de por em evidências (1) o legado de Solano Trindade transmitidos por sua filha Raquel Trindade, (2) as tensões entre o universo popular e o mundo acadêmico, (3) a fusão do legado "afronordestino" (Raquel Trindade) com o "afro-sudestino"(Alceu Estevan), (4) a produção simbólica de matriz africana e dos seus descendentes amalgamada na própria história da cidade de Campinas. Cabe observar que no momento que idealizamos e começamos a planejar os filmes tínhamos a preocupação em relação à idade avançada de Raquel Trindade, bem como à fragilidade da saúde de Alceu Estevam, o que instauraram o tom de urgência do documentário. Ambos faleceram em 2018 e o filme registrou de forma poética os seus legados.

IMAGEM 05 - Alceu Estevam (Imagem de Lillian Bento)

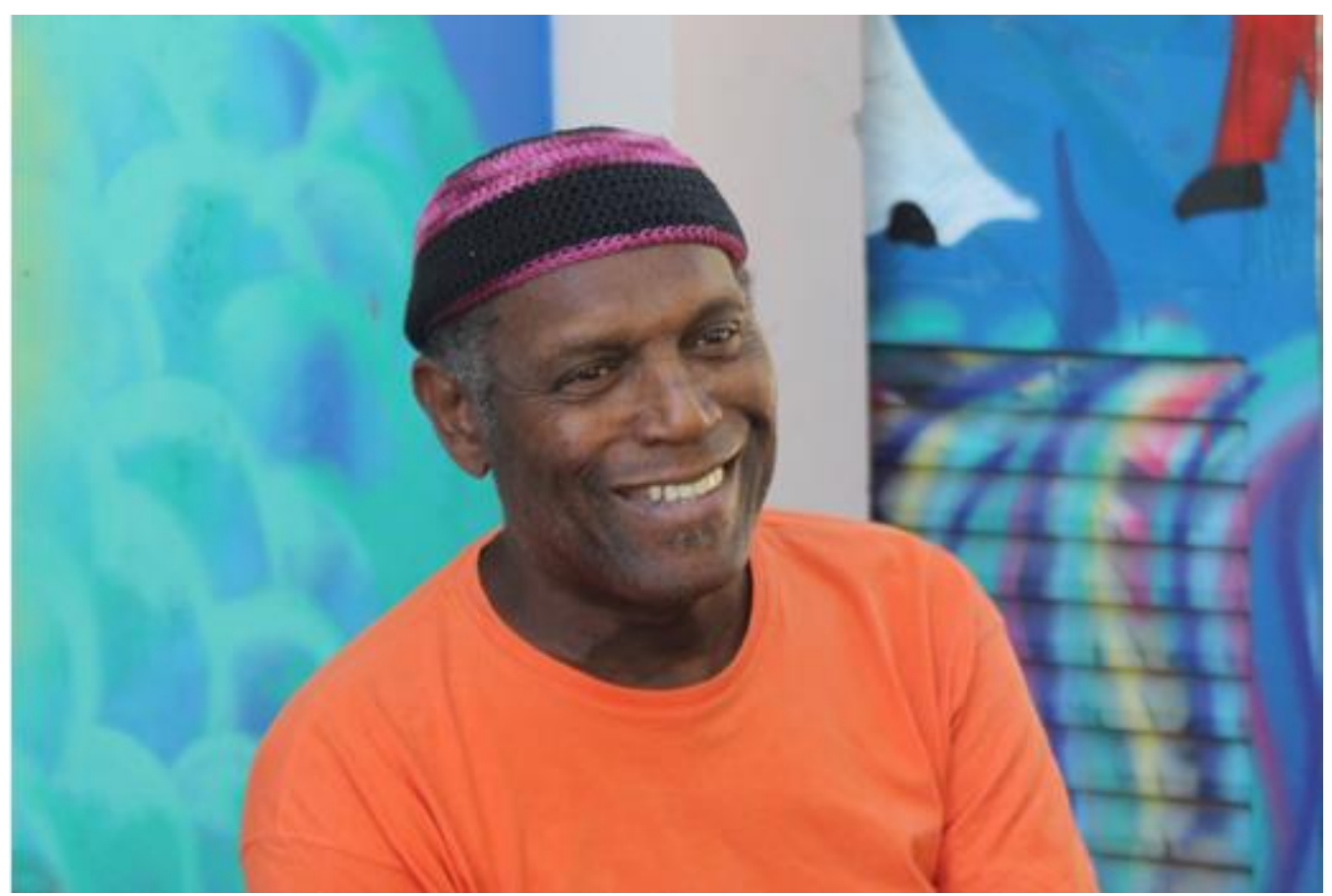


Enquanto roteiro aberto (o roteiro incluído nessa documentação refere-se ao roteiro de montagem) e tomando o grupo "Urucungos" como disparador investigativo do legado africano dentro e fora da cidade de Campinas, o documentário foi conduzido para outros afrodescendentes, cuja trajetória se enlaça à própria história do grupo e da cidade. As danças, apresentações e ensaios, bem como os líderes e artistas representativos do grupo terão lugar de destaque. Mas, tivemos a oportunidade de nos encontrar com mães de santo, como Mãe Dango, com pessoas-líderes expressivas de movimentos afroculturais campineiros, como Alessandra Ribeiro, coordenadora do Jongo Dito Ribeiro; TC, coordenador da Casa de Cultura Nação Tainã, Davi Rosa e Alessandra Gama, do Ponto de Cultura e Memória IBAÔ, entre outros. Mesmo que tais encontros não estejam no formato final do filme, foram momento de grande importância para as trocas cognitivas e afetivas que se realizaram. $\mathrm{O}$ resultado final do documentário constitui-se nas tensões que permeiam a luta contra o preconceito racial e a afirmação da resistência política e cultural, mas sobretudo o mosaico (próprio da ontologia africana) legado destas experiências. Partimos, assim, da filmagem de alguns ensaios e apresentações do "Urucungos" e, em seguida, avança-se para uma série de filmagens de sons e imagens da cidade de Campinas, da reação do público, da gravação de depoimentos e entrevistas com os integrantes (Alceu Estevam, Ana Maria Miranda, Rosária Antonia e Elizeus da Cruz) e figuras representativas da região metropolitana de Campinas diretamente relacionadas com a herança africana, em movimentos culturais e religiosos (como o ator e músico Boni, por exemplo). Os procedimentos de filmagem e o estabelecimento de uma estrutura prévia para a montagem final assentam-se sobre o conceito de um mosaico em que se reúnem diferentes registros relacionados sobre o grupo e se estende a africanidade da cidade de modo a compor uma imagem prismática, pessoal e intimista do diretor sobre todo o processo. 


\section{$(\mathrm{cc}) \mathrm{EY}$}

IMAGEM 06 - Still de A Dança da Amizade - Sinhá Rosália, João Arruda e convidados (Imagem de Felipe Bomfim)

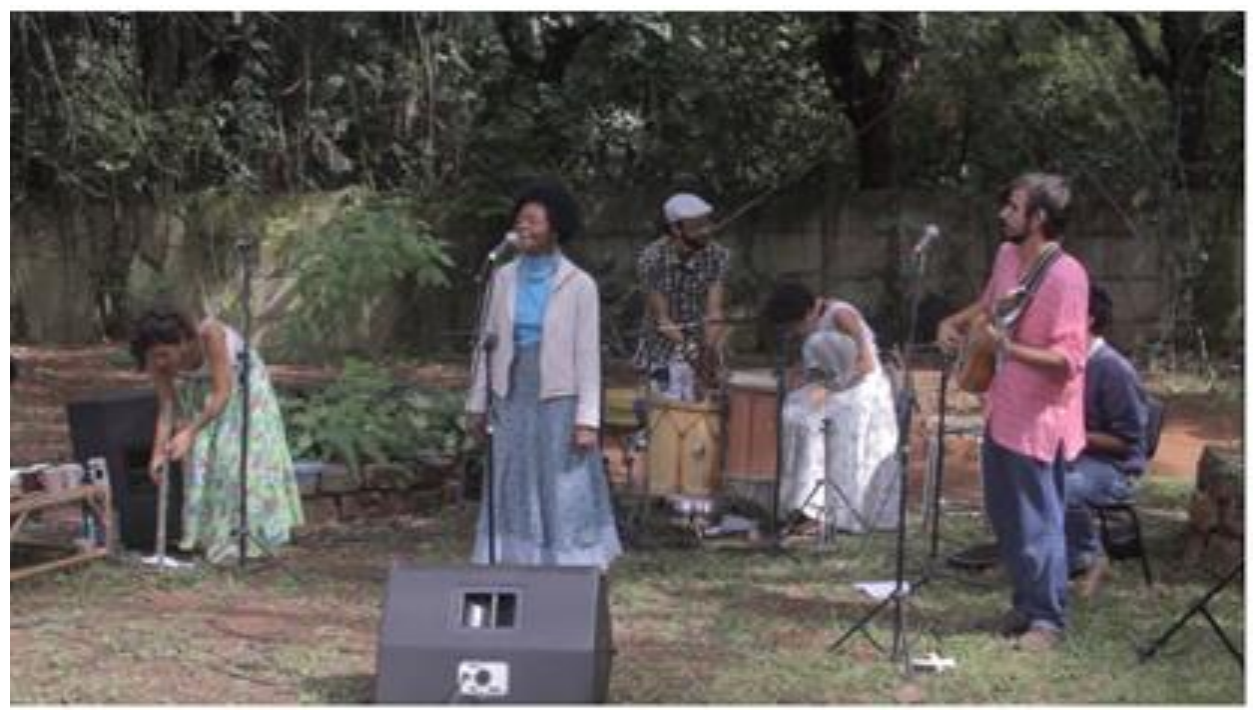

O objetivo final, portanto, foi a elaboração de uma narrativa audiovisual em que se conjuga um registro pessoal da filmagem de grupo de danças populares, e que essas imagens e sons estejam conectados com a história viva desse legado, sendo o conteúdo dessas imagens exteriores aos ensaios e espetáculos, mas diretamente conectadas com pessoas, eventos e espaços da região metropolitana de Campinas e outros territórios.

IMAGEM 07 - Bloco da Kambinda, em Embu das Artes - SP (Imagem de Lillian Bento)

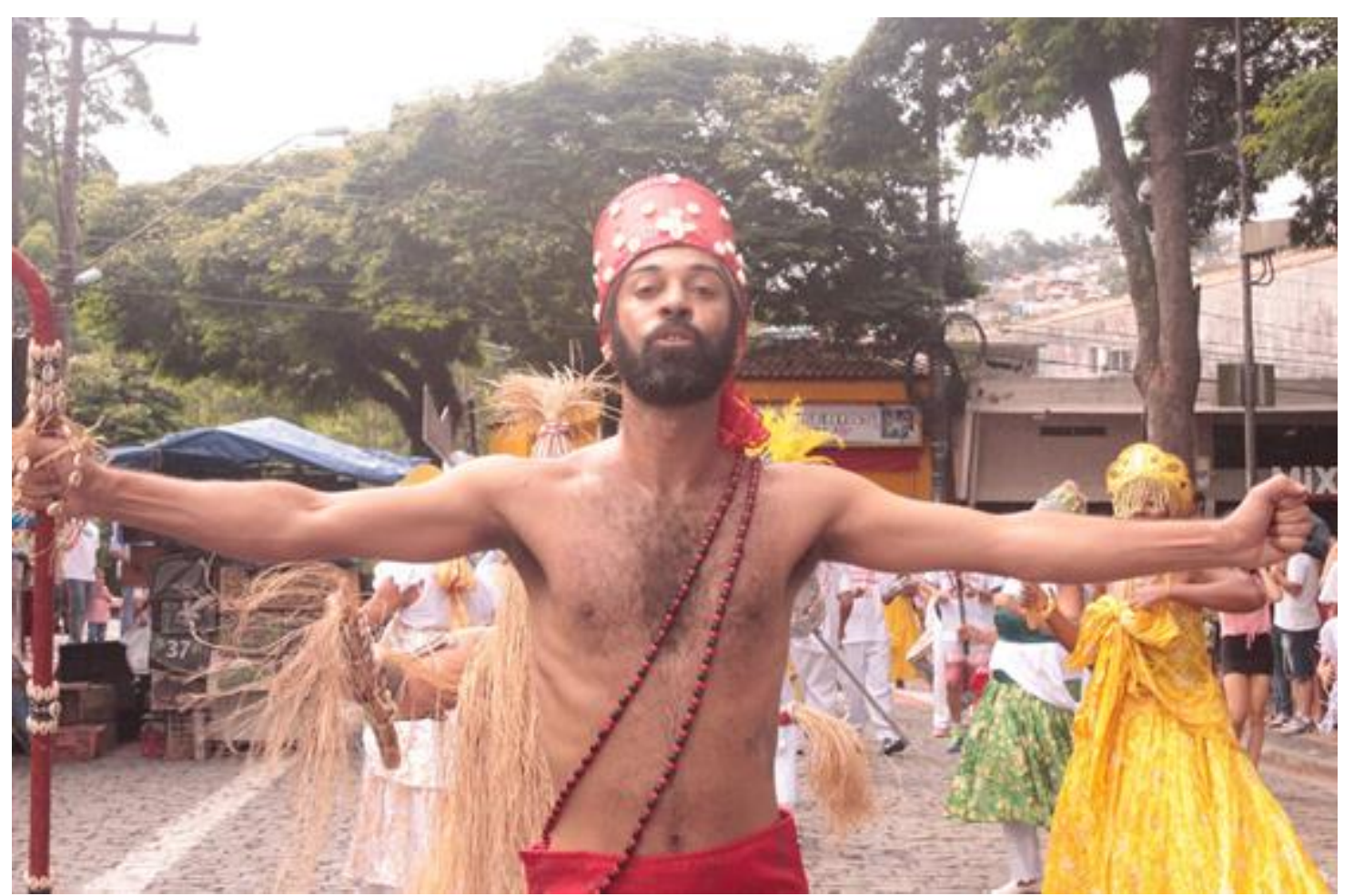




\section{$(\mathrm{cc}) \overline{\mathrm{EY}}$}

IMAGEM 08 - Ana Miranda (Fotografia de Lillian Bento)

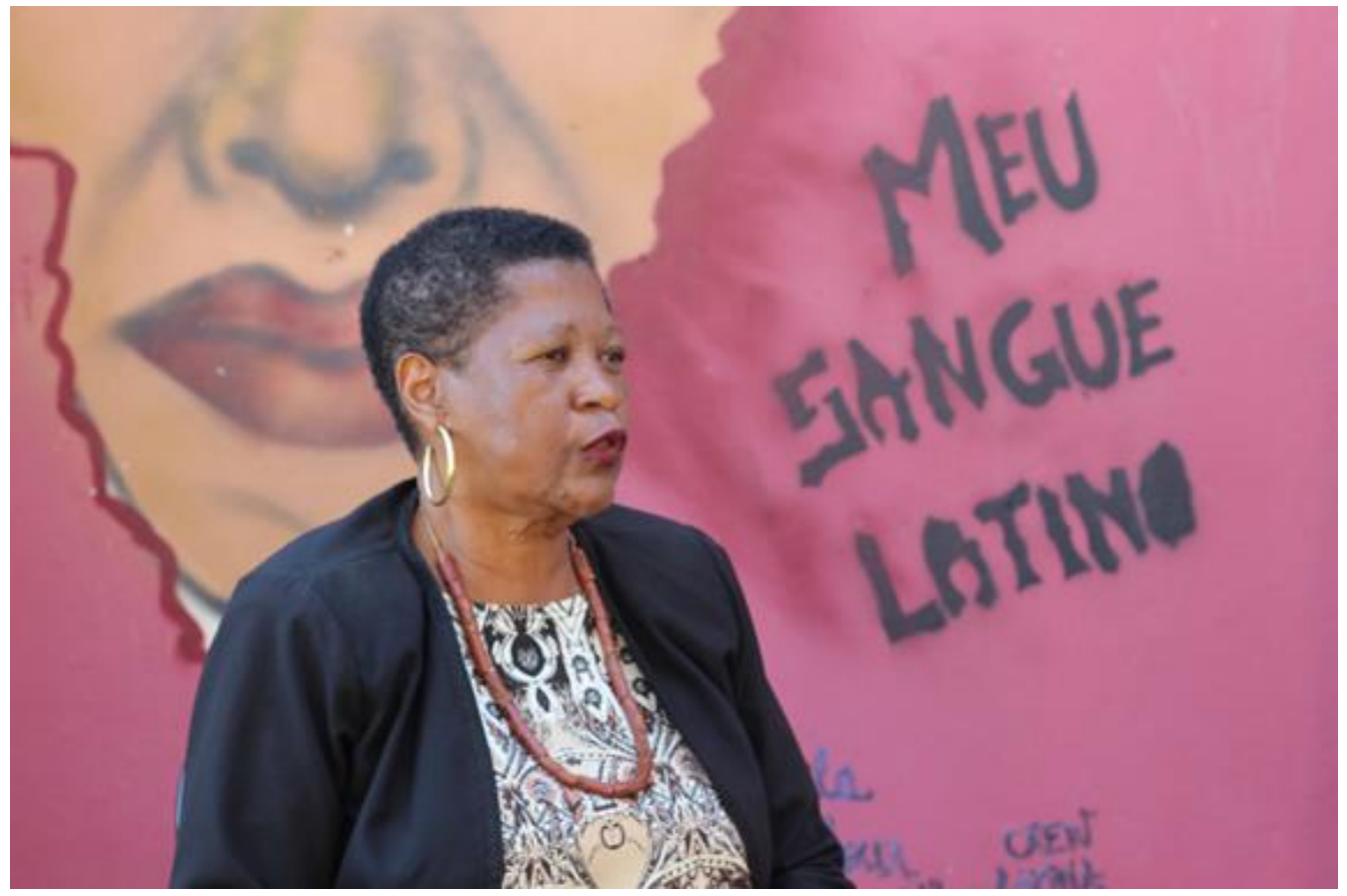

IMAGEM 09 - Zeus (Fotografia de Lillian Bento)

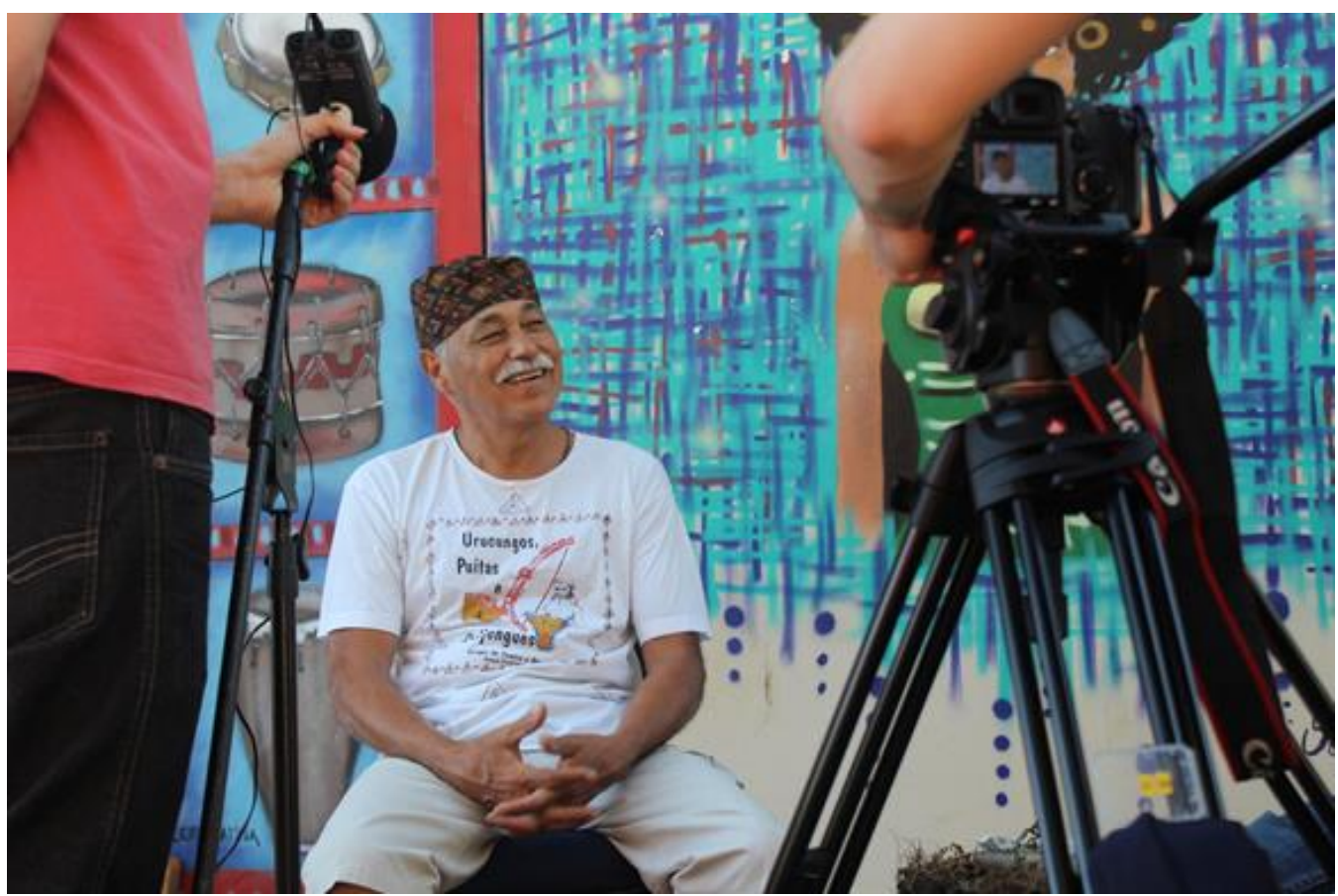

Orçamento (FICC):

Despesas com serviços

Pessoal

Assistente de produção - $\quad \mathrm{R} \$ 2.000,00$

Assistente de direção - $\quad \mathrm{R} \$ 2.000,00$

Edição - 


\section{$(\mathrm{cc}) \mathrm{EY}$}

Som Direto -

Câmera e Direção de

Fotografia -

Diretor, Produtor e

Produção Executiva -

Cachê (Grupo Urucungos

- R\$2.720,00; Raquel Trindade- R\$2.000,00 ) - Total:

Oficina de realização em

Documentários

(Pagamento de instrutores,

Material didático, e demais itens

De produção da oficina) $\quad \mathrm{R} \$ 5.300,00$

Despesas com custeio

Câmera de vídeo -

Imposto

INSS/ISS/IRRF -

Despesas com

Contador

Despesas com serviços

Cartazes -

Arte gráfica -

Folder -

Elaboração

Despesas com serviços/

fAutoração do DVD

Legendagem

Outras despesas

Total:
$\mathrm{R} \$ 2.720,00$

$\mathrm{R} \$ 2.720,00$

$\mathrm{R} \$ 8.700,00$
$\mathrm{R} \$ 5.860,00$

$\mathrm{R} \$ 300,00$

$$
\begin{gathered}
\mathrm{R} \$ 750,00 \\
\mathrm{R} \$ 90,00 \\
\mathrm{R} \$ 35.160,00
\end{gathered}
$$

$\mathrm{R} \$ 4.720,00$

IMAGEM 10 - Festa do Cururuquara (Fotografia de Alessandro Oliveira)

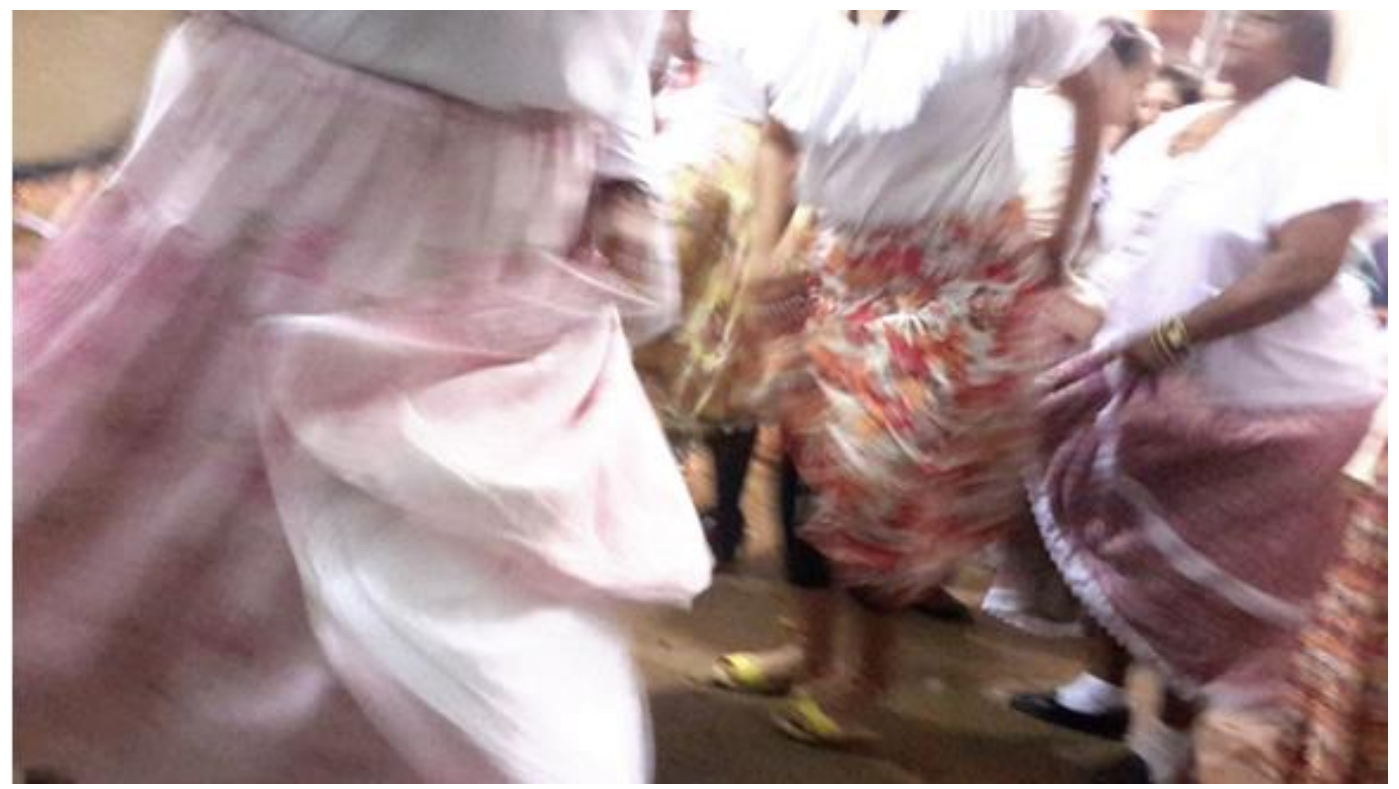


IMAGEM 11 - Festa do Cururuquara (Fotografia de Alessandro Oliveira)

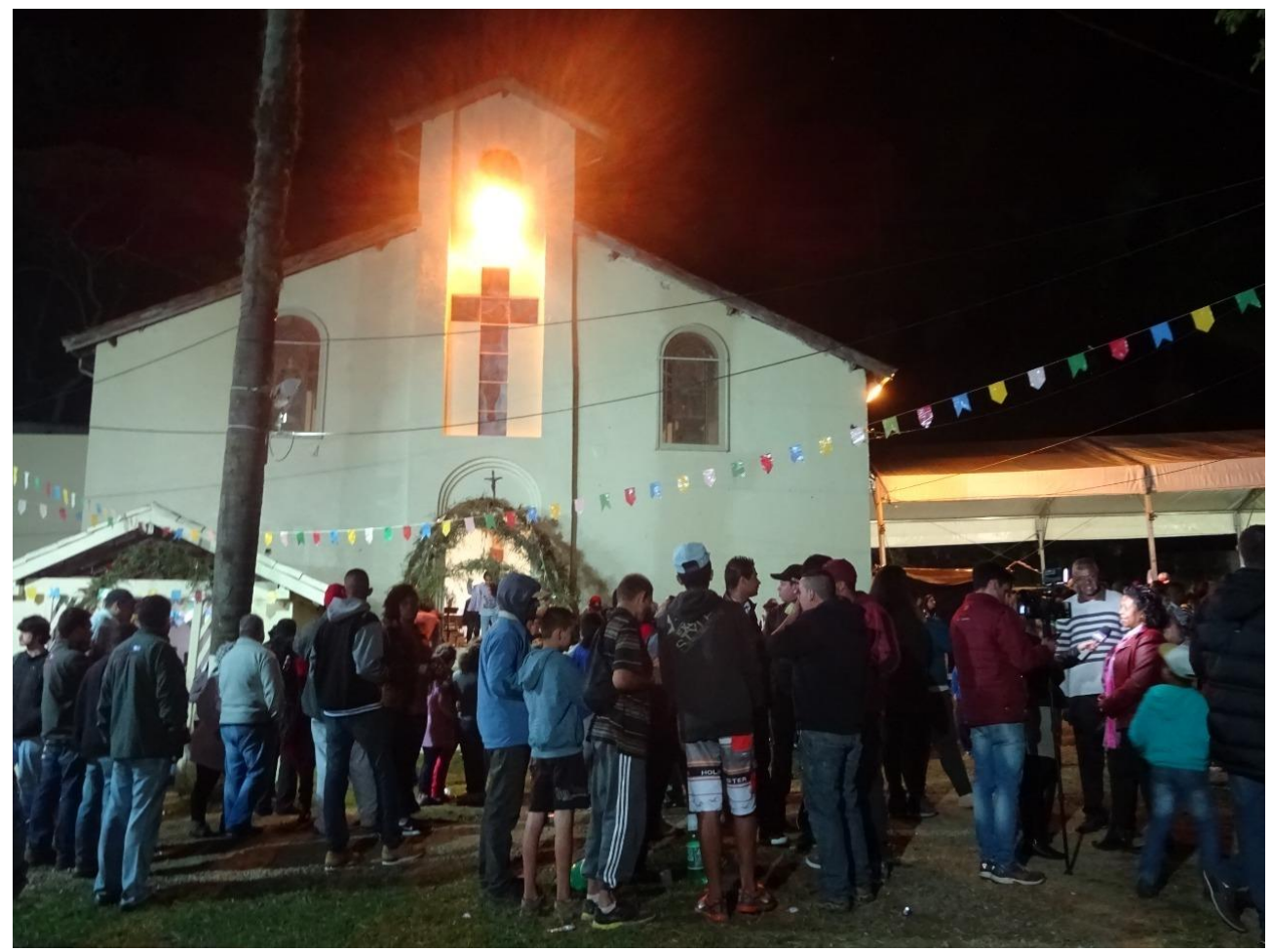

Roteiro para a montagem (publicamos aqui exatamente o material que foi enviado para a montagem, como se nota, há diferenças entre o roteiro e a versão final)

Logotipos: FICC - Fundos de Investimentos Culturais do Município de Campinas

Secretaria Municipal de Cultura

Faepex - Funde Apoio ao Ensino, à Pesquisa e à Extensão - UNICAMP

\begin{tabular}{|c|c|}
\hline IMAGEM & SOM \\
\hline 1) Abertura: Plano Geral da Cidade de & Filmagem 17.05. \\
\hline Campinas, no Canto Superior Direito, em & Som - 28'15" até 29'24" - MANTER \\
\hline Branco, o letreiro: CAMPINAS, 2015 & ESSE TEMPO, PARA OUVIRMOS \\
\hline Filmagem 18.07 - Cartão 01 - 8750 & DUAS VEZES O MESMO VERSO \\
\hline $\begin{array}{l}\text { 2) Cena do Balaio das águas. } \\
\text { Filmagem } 31.01 \text { - Cartão } 01-8074 \\
\text { 09'08' até } 09^{\prime} 48^{\prime \prime}\end{array}$ & $\begin{array}{l}\text { Filmagem } 31.01 . \text { Som - 150131-001 } \\
\text { 03'50" até 04'30" }\end{array}$ \\
\hline $\begin{array}{l}\text { 3) Vanessa apresenta Urucungos. } \\
\text { Filmagem } 04.04 \text { - Cartão } 03-8296 \\
\text { 00' até } 00 ` 25\end{array}$ & Som sincrônico \\
\hline 4) Cena da Ciranda e apresentação do & Som sincrônico \\
\hline
\end{tabular}




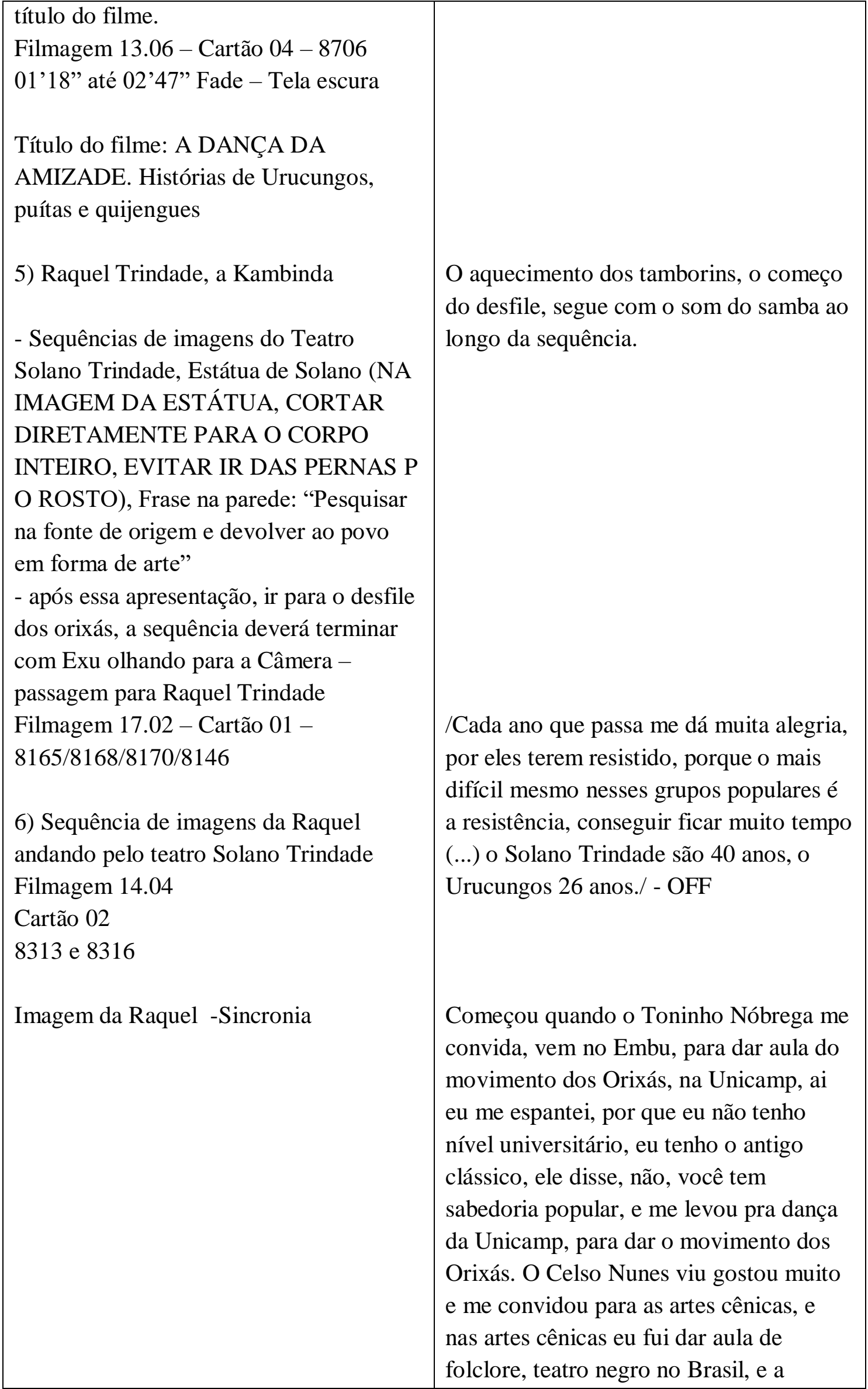




\begin{tabular}{|c|c|}
\hline $\begin{array}{l}\text { Mostrar sequencia do Grupo Solano } \\
\text { Trindade: } \\
\text { Filmagem } 18.07 \text {. Cartão } 01 \\
8764 \text { - 00'até } 35 \text { 'Jongo - } \\
8765 \text { - 00' até } 33 \text { " Samba Lenço - } \\
8766 \text { - até } 37 \text { 'Coco } \\
8768 \text { - 00' até } 01 \text { '06 - Dança dos Orixás } \\
8769 \text { - 04'49', até } 05 \text { '26" - Maracatu }\end{array}$ & 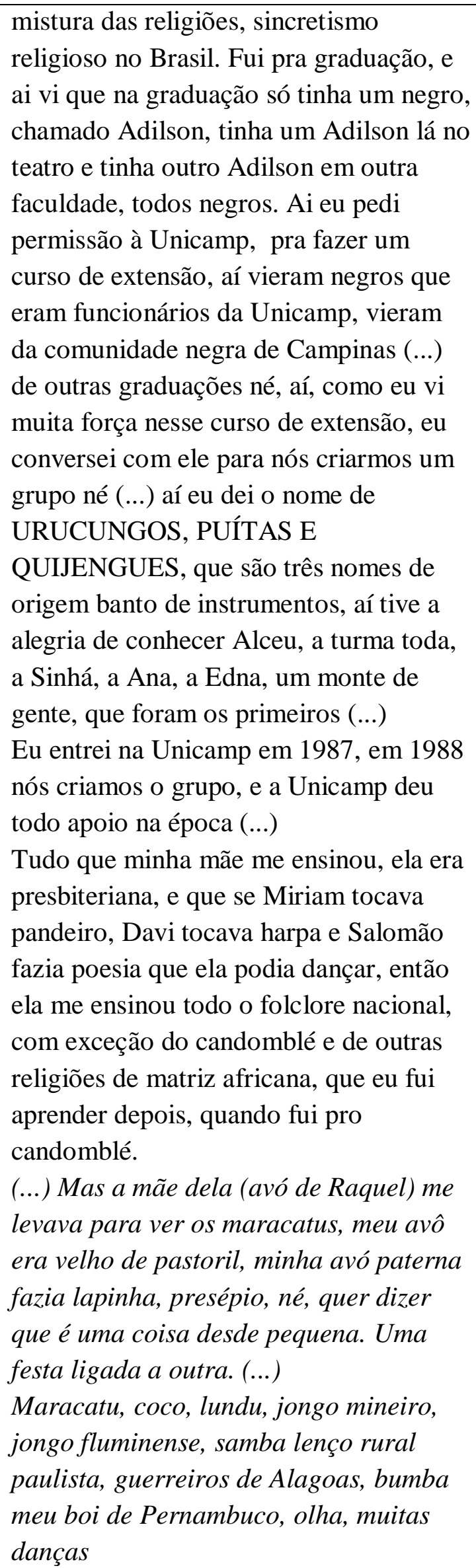 \\
\hline
\end{tabular}


A ciranda, que é da minha terra, eu nasci em Pernambuco, me criei, fui registrada no Rio, depois fui pra Europa, depois pro Embu, depois pra Campinas, e a ciranda é a dança da amizade mesmo, né (...) Por que você dança, o certo de dançar, tá de mãos dadas e traz o amigo para junto de si e torna voltar, quando troca o pé, os braços se unem, em roda né, ligados, então é a dança da amizade (...) Bom eu já tinha ensinado a eles o samba lenço rural paulista, e o Alceu pesquisou mais, e fez o samba de bumbo, que também é daquela região Campinas, Tietê, Piracicaba, que é o samba de bumbo, que é o verdadeiro samba de São Paulo, o samba lenço rural paulista e o samba de bumbo. Que antigamente a Lavapés e a Vai-vai tinham esses dois ritmos (...) Enquanto era cordão, eram esses ritmos, depois que eles passaram a escola de samba que copiaram o ritmo do Rio de Janeiro, no Rio é mais nos pés (...) Eu tava separando do $8^{a}$ marido, tava com câncer, e tava chateada com os colegas, ai eu pedi demissão. Mas a Unicamp me deu uma carta muito bonita. Eu fiquei de 87 a 1992. E depois quem me chamou, Toninho Nobrega, saiu também.

Olha o povo é muito lutador, porque por muito tempo, não houve apoio à cultura popular (...) Então, gente como meu pai, Solano Trindade, a minha mãe, Margarida da Trindade, o Abdias né, foi muita luta né, com o teatro experimental do negro, do Abdias, então foi muita luta, e de uns trinta anos pra cá é que a gente tá tendo um apoio mais forte para a cultura popular.

(...) O que não mudou foi a discriminação racial, ela tá muito pior, muito pior mesmo né, hoje tem mais negros 


\begin{tabular}{|c|c|}
\hline $\begin{array}{l}\text { Pequeno intervalo, sem som, de um plano } \\
\text { fixo espaço da entrevista, sem a Raquel - } \\
\text { Filmagem 14.04, Cartão } 03 \text { - } 8324\end{array}$ & $\begin{array}{l}\text { conscientes, são amigos de todas as raças, } \\
\text { mas tem consciência de que é negro, seu } \\
\text { valor, mas a discriminação racial está } \\
\text { cada vez pior. }\end{array}$ \\
\hline Letreiro: Ana & $\begin{array}{l}\text { O SOM DEVERÁ SER OS TAMBORES } \\
\text { DA ESCOLA DE SAMBA } \\
\text { NOVAMENTE }\end{array}$ \\
\hline $\begin{array}{l}\text { Imagens do Maracatu, pelo Urucungos: } \\
\text { Filmagem 15.02. Cartão 01. 8120/8121 }\end{array}$ & $\begin{array}{l}\text { Ana } \\
\text { Raquel falou, a gente vai dar um nome } \\
\text { para esse grupo agora, ai ela deu o nome } \\
\text { Urucungos, Puitas e Quijengues. Deu } \\
\text { esse nome para o grupo, ai não ficou o } \\
\text { grupo da Unicamp, aí começou a separar } \\
\text { né, teve alunos que se formaram, faziam } \\
\text { antropologia, foram embora da cidade, } \\
\text { foi fazer outras coisas, mas nós } \\
\text { continuamos, tocando, mesmo assim, } \\
\text { tinha muito aluno. (...) Do Urucungos } \\
\text { uma boa parte era negra, mas a maioria } \\
\text { não ficou negro porque ficou muito aluno } \\
\text { da graduação (...) } \\
\text { eu ficava assim pensando, meu sonho } \\
\text { dourado, mais de quarenta anos, sempre } \\
\text { foi fazer cultura popular, então quando eu } \\
\text { via alguma coisa assim, principalmente } \\
\text { as danças nordestinas, eu gostava muito, } \\
\text { e eu tive aquela pequena vivência com a } \\
\text { família do meu pai, a família da minha } \\
\text { mãe era assim, todo mundo gostava de } \\
\text { banda, mas a família do meu pai, todo } \\
\text { mundo samba de bumbo, escola de } \\
\text { samba, então pro meu lado paterno desde } \\
\text { pequena eu comecei a curtir um } \\
\text { pouquinho o samba né. } \\
\text { (...) } \\
\text { o Urucungos é minha segunda família, } \\
\text { pra mim é minha segunda família, eu } \\
\text { tenho minha família, logico, mas o } \\
\text { Urucungos para mim é tudo, esses meses } \\
\text { que eu fico ausente por algum problema } \\
\text { de saúde, nossa, como faz falta, o }\end{array}$ \\
\hline
\end{tabular}




\begin{tabular}{|c|c|}
\hline $\begin{array}{l}\text { Letreiro: Zeus } \\
\text { - ESSE DEPOIMENTO PODE SER EM } \\
\text { OFF, COM IMAGENS DE FIGURINOS } \\
\text { E ADEREÇOS } \\
\text { Filmagem 13.06. Cartão 01- } \\
\text { 8641/8643/8644/8648/8659/ - POR QUE } \\
\text { NENHUM DESSES PLANOS FORAM } \\
\text { UTILIZADOS? - Eu creio que ficam } \\
\text { melhores do que retomar a imagem do } \\
\text { maracatu }\end{array}$ & 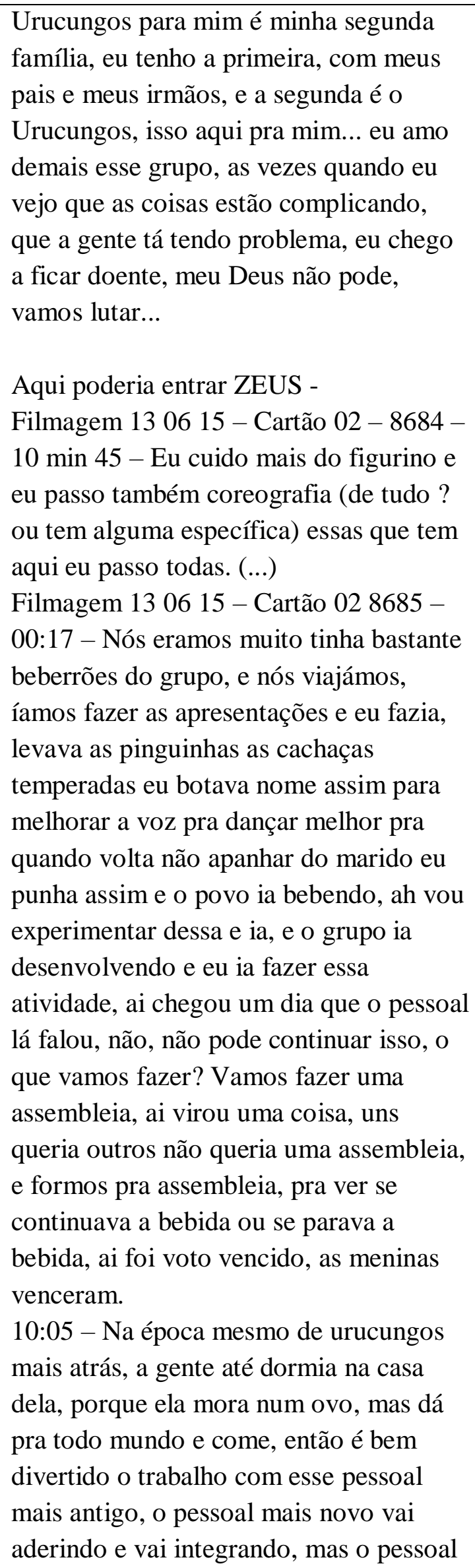 \\
\hline
\end{tabular}




\section{$(\mathrm{cc}) \mathrm{EY}$}

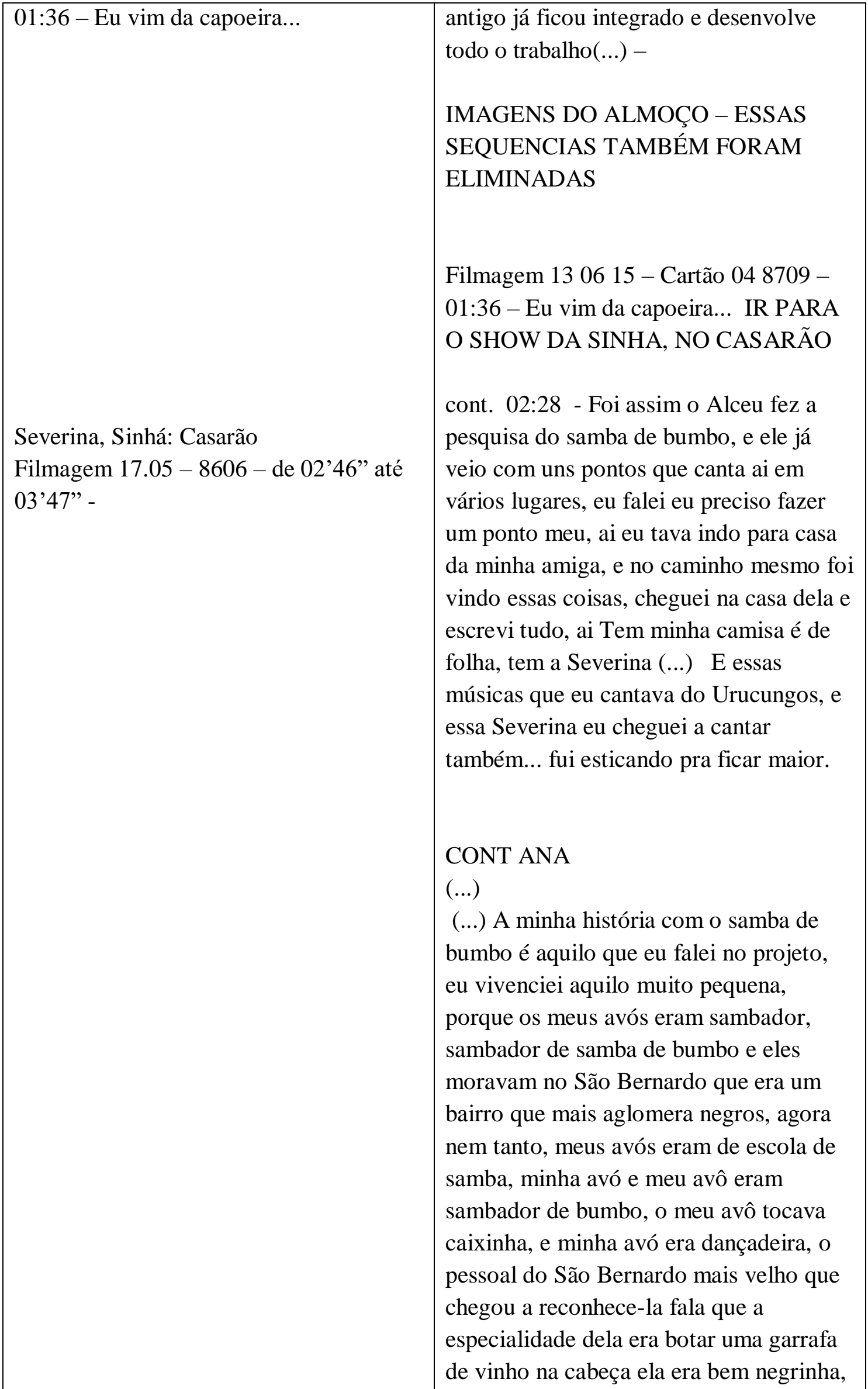




\begin{tabular}{|c|c|}
\hline $\begin{array}{l}\text { TRANSIÇÃO LENTA, SOBREPONDO- } \\
\text { SE AO DEPOIMENTO DA ANA, SUA } \\
\text { PERFORMANCE NA CATEDRAL - } \\
\text { DO 00segundos até 00:48’' ouvimos o } \\
\text { depoimento e gradativamente a musica } \\
\text { que ela canta vai tomando conta, } \\
\text { posteriormente SINCRONIA } \\
\text { SOM/IMAGEM do 00:49 até 01'25”- } \\
\text { Filmagem 04.04.15 - Cartão 03 } \\
\text { Filmagem 16.05 } \\
\text { 8543 (FACHADA DA IGREJA) /8546 } \\
\text { (OK)/8552 (BUMBO NO MURO)/8554 } \\
\text { (OK) /8558 (BUMBO)/8568 (ok)/ } \\
8572 / 8573 /\end{array}$ & $\begin{array}{l}\text { bem magrinha, botar a mão na cintura e } \\
\text { dançar na roda com aquela garrafa na } \\
\text { cabeça. } \\
\text { (...) } \\
\text { Os meus avós pegavam caminhão, ia para } \\
\text { Indaiatuba, Pirapora por ai, pra } \\
\text { cidadezinha onde tinha o samba de } \\
\text { bumbo e o samba rodava até o } \\
\text { amanhecer, eu tinha seis sete anos, meu } \\
\text { pai era o motorista do caminhão, ia } \\
\text { dirigindo e tocava mas (...) chegava } \\
\text { domingo quando a gente ia almoçar na } \\
\text { casa do meu avô tem um lado culinário } \\
\text { que eu não esqueço de jeito nenhum, } \\
\text { tinha um fogão de lenha, minha avó fazia } \\
\text { macarronada, com aquele macarrão } \\
\text { comum, molho de carne seca, e massa de } \\
\text { tomate e nós ficava ai acabava o almoço } \\
\text { e ia varrer o terreirão, terminava o } \\
\text { almoço e ia fazer a roda de samba de } \\
\text { bumbo, eu era pequenininha mas era a } \\
\text { que mais sambava, }\end{array}$ \\
\hline
\end{tabular}


Campinas, quando estava lá eu, o seu Aluísio, e o TC. Falei pra eles tá tendo um samba lá na casa do Catumba, vamos lá? Eles toparam e nós fomos, chegando lá, o samba correndo solto, ai a primeira vez que eu peguei o bumbo, eu devia tá com uns dezoito anos mais ou menos, e eu peguei o bumbo e eles gostaram (...)

o bumbo na verdade, ele é da comunidade, mas a responsabilidade de guardião desse bumbo era o meu avô, o Estevão Ernesto, que passou para o filho dele, e esse bumbo ficou indo para as romarias junto com a comunidade, quer dizer só acontecia o samba quando o bumbo do meu avô chegava. Inclusive o pessoal que vinha de São Paulo, de Jundiaí, de Rio Claro, ficava esperando o samba de Campinas acontecer, porque era Campinas que tinha a pegada do samba.

Pois bem, o meu tio, o Nestão, filho do Esnesto, ele para mim um dia e falou olha, vc vai ter que assumir o bumbo ai, porque é do seu avô, tá na família e tal, mas aí eu fui fazer teatro, e nessa história de fazer teatro eu ganhei o mundo e deixei o bumbo de lado (...)

Ai a Raquel Trindade veio fazer um curso de danças afro-brasileiras na Unicamp (...)

Passou o curso, eu resolvi trabalhar o samba de bumbo dentro do Urucungos, porque o código que ela passou para nós, que era inclusive o código do pai dela o Solano Trindade, que é pesquisar na fonte e devolver ao povo na forma de arte, eu peguei esse mote e falei vou trabalhar com isso daí. Nesse meio tempo, começou a vir todas aquelas lembranças, todos aqueles ensinamentos que estavam embutidos dentro de mim e essa passada de bastão, que eu recebi, de 


\begin{tabular}{|c|c|}
\hline $\begin{array}{l}\text { Urucungos: } \\
\text { Filmagem } 13.06 \text { Cartões } 04 \text { e } 05 \\
8726 \\
8730 \\
8731 \\
8736 \\
8737-03 \text { '12" - } 03 \text { '49 } \\
8738-00 \text { até } 01 \text { '20"' } \\
8739\end{array}$ & $\begin{array}{l}\text { também de todos os mestres que tinham } \\
\text { naquela época, que estavam presentem } \\
\text { como Chico do Rei, Catumba, Barriga, } \\
\text { Seu Agenor, Seu Ramiro, Damião, } \\
\text { (...) } \\
\text { Até então não se tinha notícia em lugar } \\
\text { nenhum que alguém estava fazendo um } \\
\text { resgate do samba de bumbo (...) } \\
\text { Foi restaurado o Trovão, que é bumbo } \\
\text { que está com o pessoal de Vinhedo, e foi } \\
\text { restaurado o Azulão, que é o outro } \\
\text { bumbo que está com o Urucungos. } \\
\text { E através desta ação, tanto o grupo de } \\
\text { Vinhedo, o Samba da Dona Aurora, } \\
\text { como o Urucungos, deu um salto no } \\
\text { sentido de trabalhar } \\
\text { apresentações, com várias oficinas nas } \\
\text { escolas (...) foi um renascimento do } \\
\text { samba de bumbo. } \\
\text { (...) }\end{array}$ \\
\hline
\end{tabular}




\begin{tabular}{|c|c|}
\hline $\begin{array}{l}\text { A PARTIR DOS } 32 \text { ' } 10 \text { ' - sobrepor a voz } \\
\text { do Alceu com a imagem das duas } \\
\text { cantando - bem baixinho - até } 32 \text { '37' - } \\
\text { depois a imagem e o som sincronizam no } \\
\text { Alceu novamente }\end{array}$ & $\begin{array}{l}\text { (...) a gente entende que há dois } \\
\text { processos nisso tudo, um que é } \\
\text { preservação da memória, aliás digo 03, } \\
\text { preservação da memória, a questão do } \\
\text { conhecimento, a gente tem que entender } \\
\text { essa cadeia do conhecimento, do } \\
\text { processo, para que nós possamos fazer as } \\
\text { nossas próprias coisas né, que a gente } \\
\text { possa ter voz, na verdade a gente precisa } \\
\text { ter voz, ao mesmo tempo que eu estou } \\
\text { aqui, eu poderia estar do outro lado } \\
\text { produzindo conteúdo, e você transformar } \\
\text { isso numa estética que ela possa ser } \\
\text { valorizada nos canais de conhecimento } \\
\text { como nas escolas públicas, nos } \\
\text { movimento socias, nas universidades, no } \\
\text { cinema, na música, é isso... } \\
\text { (...) o samba de bumbo foi um código que } \\
\text { foi imprimido aqui na cidade, então eu } \\
\text { acho que ele é o primeiro elemento da } \\
\text { nossa cultura, (...) } \\
\text { O Urucungos gente, é um grupo assim } \\
\text { que, é uma coisa que tem que ser } \\
\text { estudada, porque nós não temos assim } \\
\text { uma, um estudo avançado de como nós } \\
\text { vamos trabalhar o grupo daqui a cinco } \\
\text { anos (...) - excluir essa parte - } \\
\text { EXCLUIR. O Urucungos a gente não } \\
\text { sabe como a gente organiza ele, a gente } \\
\text { vai fazendo as coisas, e vai acontecendo, } \\
\text { e nesse processo já fazem } 26 \text { anos que } \\
\text { estamos assim (...) } \\
\text { SARACURA } \\
\text { 06min12 }\end{array}$ \\
\hline
\end{tabular}


Boni

Filmagem 18.07 - 8763, 5min 15 -

$\mathrm{Eu}$ - Do Urucungos saiu seu projeto do

Saracura,

Boni - O Saracura saiu de dentro do

Urucungos, a Luiza, a Vani, o Robisinho,

o Robisinho chegou bebezinho no

Urucungos, cresceu no Urucungos, o

Robisinho, a Vani e a Luiza que é uma

família né, a Sinhá esteve com a gente no começo.

$\mathrm{Eu}-\mathrm{E}$ o repertório é de samba paulista

B - Samba paulista, que eu pensei... com esse incentivo dado a nossa cultura, e eu me sentia a vontade, para que era uma coisa assim, canta samba paulista para mim é gostoso, eu gosto de cantar maracatu, adoro cantar boi, mas quando eu to cantando samba paulista to falando de mim mesmo, do meu povo. Então

Filmagem 17.05, Cartão 03, 8632

Imagens das árvores, da apresentação da Sinhá.

Plano fixo na sede do Urucungos

Letreiro: Um filme de Gilberto

Alexandre Sobrinho comecei cantando esse samba, o batuque de Pirapora, que fala "Eu era menino, mamãe disse vamo embora" eu tinha uma vontade louca de cantar esse samba (....) mostrando o samba paulista, o samba rural e o samba urbano (...) Como um rio que passa e vai interferindo na vegetação e criando uma floresta.

Entra música com Sinhá - Filmagem 17.05.15 - CARTAO 01 - 8601 - 00:50" até 01 ' 33 " 
IMAGEM 12 - Festa no Cururuquara - Entrevista com Alceu e Rosa (Fotografia de Alessandro Oliveira)

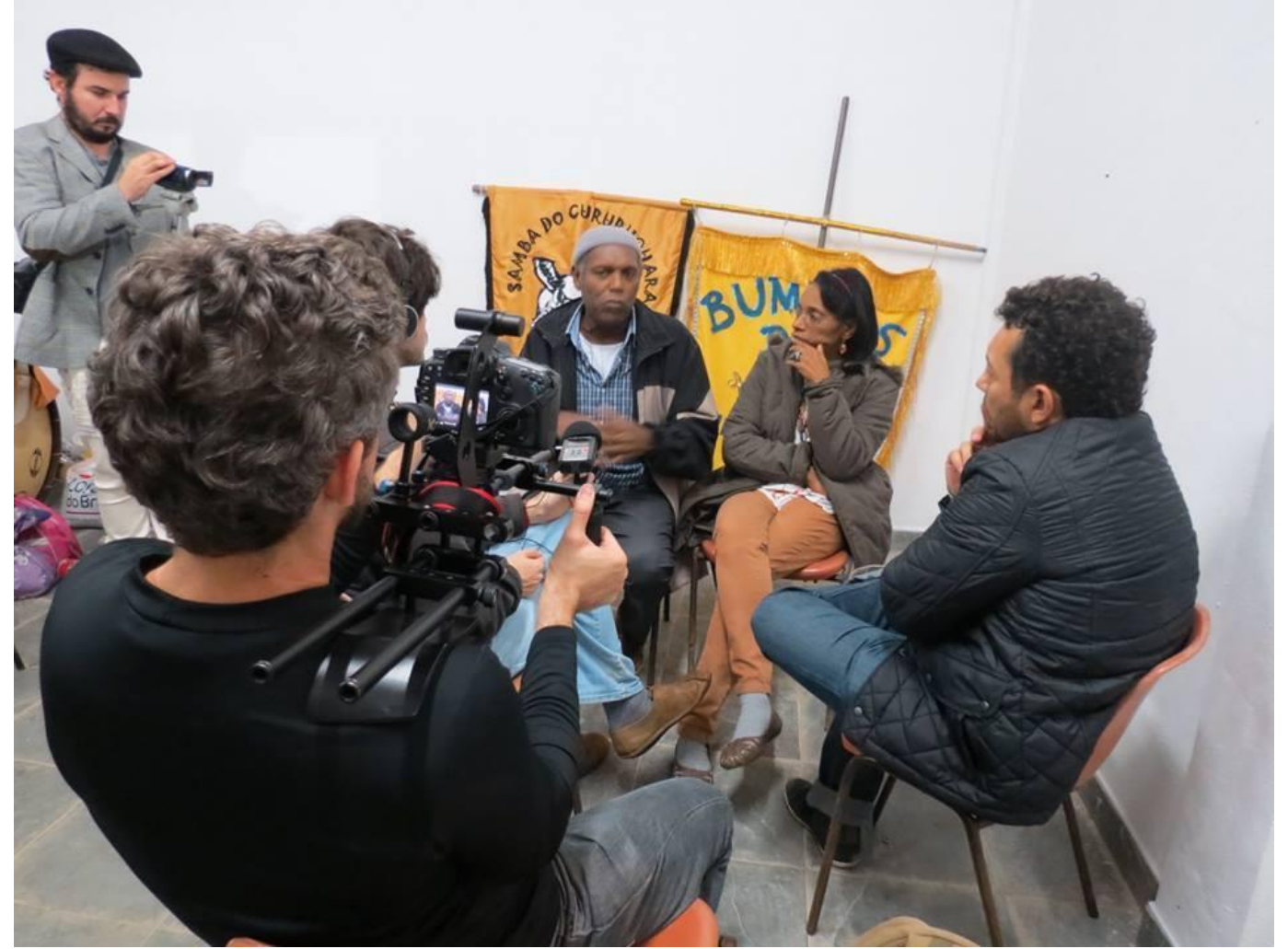

Ficha Técnica:

A Dança da Amizade - Histórias de Urucungos, Puítas e Quijengues (2016)

Sinopse: A trajetória artística e de resistência afro-brasileira do Grupo Urucungos, Puítas e Quijenques. Surgido em Campinas, na UNICAMP, no final dos anos 1980, por iniciativa da pernambucana Raquel Trindade, artista e continuadora do legado de seu pai, Solano Trindade o grupo mantém vivo o repertório de tradições populares nordestinas, é uma das principais vozes do samba de bumbo, vertente do samba paulista e emblema da ausência de negros em uma universidade pública.

Direção, roteiro e produção -Gilberto Alexandre Sobrinho

Concepção e Pesquisa - Alessandro Oliveira e Gilberto Alexandre Sobrinho

Direção de Fotografia - Felipe Bonfim

Som direto - Victor Negri

Montagem - Marina Pires

Assistência de Produção - Alessandro Oliveira

Assistência de Direção - Alessandro Oliveira

Fotografia (Still) - Lillian Bento

Edição de Som e Mixagem - Bruno Carneiro

Correção de Cor - Henrique Cartaxo

Grupo de Teatro e Danças Populares Urucungos, Puítas e Quijengues

Alceu Estevam

Ana Maria Miranda

Angélica Fátima de Paula

Cibele Rodrigues

Ernestina Estevam 
Evelyn Pires

Jacinta Brito

Luiza Benedita de Arruda Almeida

Maria Lucia Cardoso

Manuela Antonio

Mayra Luiza Rodrigues

Rosangela M. Mateus Santos da Silva

Poliana Sales

Renata Damas

Roberto Bonifácio

Robson Vieira Lopes

Rosa Pires Sales

Rosária Antonia

Vandir Gomes Barbosa

Ivani Vieira Lopes

Elizeus da Cruz

E as crianças:

Alice Sales

Naya Damas

Tais Bueno

Tom Damas

Crianças que não aparecem no filme:

Eloa Bueno

Gabriela Bueno

Lais Helena Pereira Martins

Laura Martins Pereira

Com a participação dos seguintes grupos

Bloco da Kambinda

João Arruda (violão e voz) com Sinhá Rosária (voz) e convidados: Esther Alves (Flauta, percussão e voz), Cris Monteiro (percussão e voz), Yandara Pimentel (percussão e voz), Franco Galvão (violão 7 cordas)

Grupo de Samba de Roda da Dona Aurora

Samba de Bumbo do Cururuquara

Grupo de Samba Saracura: Roberto Bonifácio, Daniel Bueno, Marcos Simplicio, Robson

Vieira Lopes, Ivani Vieira Lopes e Daniel Bueno

Crédito de Imagem

Teatro Popular Solano Trindade - Embu das Artes - SP

Centro histórico de Embu das Artes

Catedral Metropolitana de Campinas-SP

$128^{\circ}$ Festa do Cururuquara - Santana do Parnaíba-SP

Sede do Grupo Urucungos Puítas e Quijengues

Agradecimentos:

Ponto de Cultura e Memória Ibaô

Organizadores da $128^{\circ}$ Festa do Cururuquara - Santana do Parnaíba

Marcelo Tomé

Letizia Nicoli 
A principal fonte de pesquisa bibliográfica para este documentário é a dissertação de mestrado "Danças populares brasileiras entre a tradição e a tradução: um olhar sobre o grupo

Urucungos, Puítas e Quijengues", de Alessandro José de Oliveira (Unicamp, 2004)

Financiamento:

FICC - Fundos de Investimentos Culturais do Município de Campinas - Secretaria Municipal de Cultura (Edital 2014)

FAEPEX - Fundo Apoio ao Ensino, à Pesquisa e à Extensão - UNICAMP

Distribuição:

O curta-metragem está disponível no Youtube:

https://www.youtube.com/watch?v=udtoDfLh-_Y

Exibições em Mostras e Festivais:

2016 - 10 $0^{\text {a }}$ Mostra Curta Audiovisual de Campinas (Campinas, SP)

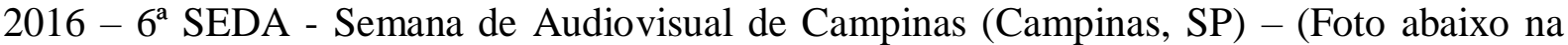
exibição no Ponto de Memória e Cultura IBAÔ)

2016 - $2^{\circ}$ Cine Bodó (Manaus, AM)

2016 - Projeção no MIS, Museu da Imagem e do Som (Campinas, SP)

2016 - $6^{\circ}$ Cine Debate - Núcleo Afro-Brasileiro de Ilha Solteira (NABISA)

2017 - 10 Encontro Cinema Negro Zózimo Bulbul, Africa, Brasil e Caribe (Rio de Janeiro,

RJ - Internacional)

2017 - $2^{\circ}$ Cine Tamoio - Festival de Cinema de São Gonçalo (São Gonçalo, RJ)

2017 - $8^{\circ}$ Festival Internacional Pachamama - Cinema de Fronteira (Rio Branco, AC)

2017 - Projeção no Espaço CHÃO (São Luís, MA)

2017 - Projeção ADUNICAMP - Associação dos docentes da Unicamp (Campinas, SP)

2017 - Projeção Cineclube Vagalume, Faculdade de Ciências e Letras, Unicamp - Limeira (Limeira, SP)

2018 - Mostra SESC de Cinema - Cinesesc - São Paulo - SP

2018 - Casa de Eva - Campinas - SP 


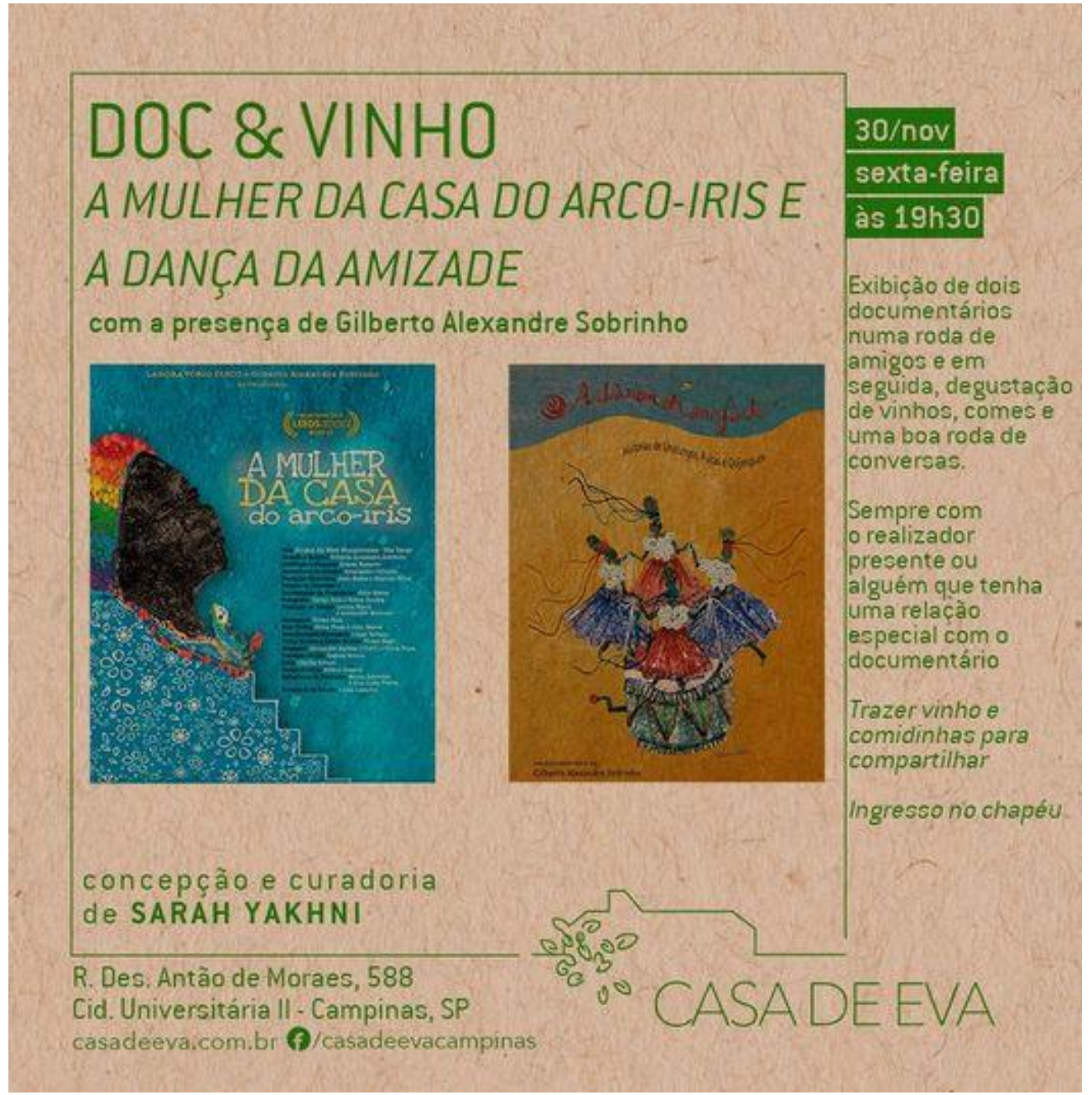

2019 - Cineclube Terracota - Campinas - SP

2019 - Mostra "Múltiplas Vozes da Experiência Negra", SESC- Campinas, Campinas - SP 2019 - Centro Cultural Brasil - Moçambique (Maputo)

\section{REFERÊNCIAS}

OLIVEIRA, Alessandro José de. Danças populares brasileiras entre a tradição e a tradução: um olhar sobre o grupo Urucungos, Puitas e Quijengues. 2004. Dissertação (mestrado) - Universidade Estadual de Campinas, Instituto de Artes, Campinas, SP. Disponível em: http://www.repositorio.unicamp.br/handle/REPOSIP/284174. Acesso em: 21 Dec. 2020.

SODRÉ, Muniz. A verdade seduzida: por um conceito de cultura no Brasil. 3. ed. Rio de Janeiro, RJ: DP\&A, 2005.

Recebido em: 22 de dezembro de 2020

Aceito em: 22 de dezembro de 2020 